TITLE:

\title{
Management of metastasis to the thyroid gland.
}

$\operatorname{AUTHOR}(S)$ :

Ishikawa, Masaaki; Hirano, Shigeru; Tsuji, Takuya; Ito, Juichi

\section{CITATION:}

Ishikawa, Masaaki ...[et al]. Management of metastasis to the thyroid gland.. Auris, nasus, larynx 2011, 38(3): 426-430

\section{ISSUE DATE:}

2011-06

URL:

http://hdl.handle.net/2433/139807

\section{RIGHT:}

(c) 2010 Elsevier Ireland Ltd.; この論文は出版社版でありません。引用の 際には出版社版をご確認ご利用ください。; This is not the published version. Please cite only the published version. 


\section{Introduction}

Metastasis to the thyroid gland (MTG) is rarely diagnosed clinically but the incidence of MTG at autopsy is not rare ${ }^{1-8}$ (Table 1). Although the incidence of MTG at autopsy in unselected populations is low $(0.5 \sim 2.8 \%)$, the incidence in populations with known primary cancers is reported to be much higher (3.9 24.2\%). The most frequent primary sites are breast and lung.

The number of clinical cases with MTG has been gradually increasing ${ }^{9-12}$, probably because of the development of various diagnostic techniques, including computed tomography (CT), F-18-fluorodeoxyglucose positron emission tomography (FDG-PET), ${ }^{13}$ and fine needle aspiration biopsy (FNAB). ${ }^{12}$

The treatment of MTG is controversial because the prognosis of these cases is basically poor, depending on the primary sites. Thyroidectomy for these patients is relatively invasive, and may not be effective in prolonging of survival time: however it may help preserve quality of life (QOL) in some circumstances because extension of MTG to surrounding tissues such as the trachea, esophagus, recurrent laryngeal nerve, or the larynx tends to worsen QOL. The decision to perform thyroidectomy may depend on the condition and needs of the individual 
patient. The aims of this current report are to assess the clinical characteristics of MTG, and the role of thyroidectomy. We reviewed the charts of our patients with MTG who previously underwent thyroidectomy, and performed a literature review.

\section{Methods}

Patients who underwent thyroidectomy between 1988 and 2008 for MTG at the Kyoto University Hospital Department of Otolaryngology-Head and Neck Surgery were chart-reviewed. Patients with lymphoma or with tumors that directly invaded the thyroid from adjacent organs were excluded. Ultrasonography (US), CT, and FDG-PET were the preoperative imaging studies used for diagnosis. Cytological and histological diagnostic examinations were performed on biopsies from every patient. Metastatic cancer in the thyroid gland was confirmed by histological comparison of the thyroid specimen with the primary tumor. Immunohistochemistry of both primary and thyroid tumors was also performed if required. This study was approved by ethic committee of Kyoto University.

\section{Results}


Patient Demographics

Thyroidectomy was performed in 970 patients with malignant tumors of the thyroid.

Four patients ( 1 male and 3 female) were diagnosed with MTG. Their ages ranged from 48 to 69 years (median, 60 years) (Table 2). The incidence of MTG in thyroid malignancies was $0.4 \%$.

Each of the 4 patients had a different primary tumor, which included lung, liver, breast, and colon cancers, and each patient had undergone surgical resection and/or chemotherapy for the primary tumor before detection of MTG.

Clinical presentation of metastasis to the thyroid gland

Three of 4 patients were asymptomatic, and their MTGs were incidentally detected by follow-up FDG-PET or CT. None of the patients had thyroid tumor calcifications detected by US.

One patient (case 3) presented with rapidly-growing thyroid nodules and skin redness involving the neck to the left precordial region because of invasive breast cancer in the left breast. The patient received steroid therapy for 1 week to prevent edema of the larynx but she gradually complained of dysphagia and dyspnea.

The time to detection of MTG after primary tumor diagnosis ranged from 1 to 3 years. 
All patients had concurrent nodal and distant metastases (lung or brain).

Fine needle aspiration biopsies (FNABs) were used for diagnoses, which indicated adenocarcinoma in all cases: however it was difficult to definitively differentiate metastatic cancers from primary thyroid cancers. In 3 cases the diagnoses were further confirmed by postoperative immunohistochemistry.

\section{Treatment and prognosis}

Three patients underwent total thyroidectomy, and 1 patient (case 4) underwent subtotal thyroidectomy. There were no major postoperative complications observed, such as recurrent laryngeal nerve paralysis, hematoma, or respiratory distress.

Three patients died from their primary disease 3 to 23 months after thyroidectomy, with a median survival time of 10 months. No patient developed cervical recurrences or respiratory symptoms. One patient (case 1 with lung cancer) has survived tumor-free for 1 year after thryoidectomy. She was treated with chemotherapy after thyroidectomy for intrapulmonary metastasis with complete resolution of the lung metastasis. 
Representative case presentation (case 1)

A 67-year-old woman underwent left upper lobectomy by video-assisted thoracoscopic surgery (VATS) for lung carcinoma. The pathologic diagnosis was adenocarcinoma with mixed subtypes (acinar and papillary), and was staged pT2NOMO. Two years later, a follow-up FDG-PET scan detected hypermetabolic lesions in the right lobe of the thyroid gland, as well as in the right upper lobe of the lung (Figure 1). The patient had no symptoms caused by the thyroid tumor. Physical examination revealed a hard $1 \times 1 \mathrm{~cm}$ in the right lobe of the thyroid gland. Her regional cervical lymph nodes were not palpable. US and CT revealed a tumor without calcification in the right lobe of the thyroid gland (Figure 2A), and chest CT revealed 1 nodule in the right upper lobe of the lung without apparent lymphadenopathy, which corresponded to the same region of the FDG-PET findings (Figure 2B). Laboratory data revealed a serum carcinoembryonic antigen (CEA) of $1.3 \mathrm{ng} / \mathrm{ml}$ (normal range, $0-5.0$ ). Free triiodothyronine (FT3) was $2.8 \mathrm{pg} / \mathrm{ml}$ (normal range, 2.3-4.0), and free thyroxine (FT4) was 1.04 $\mathrm{ng} / \mathrm{dl}$ (normal range, 0.8-1.6). Thyroid stimulating hormone (TSH) was $10.8 \mathrm{IU} / \mathrm{ml}$ (normal range, $0.5-5.0$ ) and thyroglobulin was $42.4 \mathrm{ng} / \mathrm{ml}$ (normal range, 0-45). FNAB cytology of the thyroid tumor revealed adenocarcinoma with papillary structure, which was suspicious for primary 
thyroid tumor or lung cancer metastasis.

After consultation with the thoracic surgeon, a total thyroidectomy was performed.

Histology of the thyroid tumor showed papillary structures (Figure 3A). Immunohistochemically, the tumor cells were negative for thyroglobulin (Figure 3B) and positive for cytokeratin 19 (CK19) (Figure $3 \mathrm{C}$ ), and the thyroid tumor was diagnosed as a lung cancer metastasis.

Postoperatively, the patient was treated with gefitinib with good response. The lung nodule disappeared on follow-up CT, and the patient is alive without disease for one year after thyroidectomy.

\section{Discussion}

The incidence of MTG has been thought to be very low. According to the report of

Wychulis et al., ${ }^{9}$ there were 10 cases with MTG out of 20,262 patients $(0.05 \%)$ who underwent operation on the thyroid. The current case series also demonstrates a $0.4 \%$ incidence of MTG among patients undergoing thyroidectomy in our department over 20 years for a diagnosis of malignant thyroid tumor. According to the reports from Mayo clinic $^{9-12}$, however, the number of MTG cases has been gradually increasing. It is suggested that the recent development of 
diagnostic techniques such as CT, FDG-PET, ${ }^{13}$ or FNAB ${ }^{12}$ may improve the ability to detect MTG.

The most frequent sites of primary malignancies metastatic to the thyroid are reported to be kidney, followed by breast and lung (Table 3). ${ }^{9-12,14-18}$ Nakhjavani et al. ${ }^{15}$ reported the frequency of kidney, lung, and breast primaries as 33\%, $16 \%$, and $16 \%$, respectively. Our study also detected lung and breast cancers as the origin of metastasis in 1 patient each in addition to colon and liver cancer metastases.

Metastasis to the thyroid gland is a clinical diagnostic problem. The reasons for this are thought to be as follows ${ }^{8}:$ (1) most patients are asymptomatic: (2) the sizes of the lesions are small in most cases: (3) a small sample size by FNAB makes a definitive pathologic diagnosis difficult: (4) the time to detection is long in some cases: and (5) the metastatic lesion is solitary in most cases. These reasons make differentiation from the primary thyroid tumor difficult.

A malignant thyroid tumor is thought to be much more likely to be metastatic than primary in patients with a history of cancer. ${ }^{5}$ It has been reported that an interval of 15 years elapsed from the diagnosis renal cell carcinoma to the detection of thyroid metastasis. ${ }^{17}$ In our series, the time to detection ranged from 1 to 3 years. Therefore, it is important to include 
metastasis to the thyroid gland in the differential diagnosis when a thyroid tumor is found in a

patient with a history of cancer.

It has been reported that a palpable thyroid nodule was found in $72 \%$ of patients with

MTG. ${ }^{18}$ The other $28 \%$ of patients were asymptomatic and a thyroid mass was incidentally detected by various imaging studies. However, as seen in case 3 in our series, there are some patients who complain of a rapidly-growing mass in the neck, dysphagia, or hoarseness. In these patients it is necessary to distinguish MTG from anaplastic thyroid tumors.

US, CT, FDG-PET, and tumor markers specific to the primary tumor are useful diagnostic tools for early detection of MTG. Clinically FDG-PET has been frequently used for detection of recurrent cancer. In some cases, MTG is occult, and FDG-PET should be a useful imaging modality for these patients. Indeed, in case 1 we incidentally detected a thyroid tumor by FDG-PET.

FNAB is also useful for the diagnosis. ${ }^{12}$ We suspected MTG from the findings of FNAB in all the patients of this present series, but the diagnosis was not definitive. It is relatively difficult to accurately diagnose MTG by FNAB only, and it has been reported that the accuracy rate of FNAB for MTG was only 50\%, although the percent of cases positive for malignancy was 
$90 \% .{ }^{14}$ Immunohistochemistry is a useful method for improving the accuracy of diagnosis, because metastasis to the thyroid gland can be distinguished from primary thyroid tumor by immunohistochemical demonstration of thyroglobulin. ${ }^{19}$ However, $70 \sim 80 \%$ of anaplastic thyroid tumors are negative for thyroglobulin. ${ }^{20}$

Although thyroidectomy for MTG is recommended by some authors, ${ }^{14-16}$ there is no clear consensus for therapy. One reason for this may be because the recommendations were based on case reports or uncontrolled studies. In a controlled study, ${ }^{18}$ thyroidectomy was useful in preventing further dissemination of the primary tumor in patients whose metastases were limited only to the thyroid, although it did not contribute to prolonged survival. In addition, metastasis to the thyroid gland does not always mean poor prognosis, which depends on the dissemination and advanced stage of the primary tumor. In our series, thyroidectomy was performed for all of the MTG patients in order to prevent difficulty in respiration and/or swallowing. Although survival after thyroidectomy was poor in 3 of 4 cases, thyroidectomy was thought to contribute to maintaining QOL in respect to respiratory and swallowing functions. In addition one patient with lung cancer MTG remains alive without disease after thyroidectomy followed by chemotherapy. 
In conclusion, it is still difficult to determine which patient with MTG is a good candidate for thyroidectomy, but we suggest that patients complaining of dysphagia or dyspnea, or those at high risk for developing respiratory distress in the near future, should undergo thyroidectomy.

Acknowledgement

This study was supported in part by the grant from Takeda Foundation. 


\section{References}

1) Rice CO. Microscopic metastases in the thyroid gland. Am J Pathol 1934; 10:407-12

2) Abrams HL, Spiro R, Goldstein N. Metastases in carcinoma: analysis of 1000 autopsied cases. Cancer 1950; 3:74-85.

3) Hull $\mathrm{OH}$. Critical analysis of two hundred twenty-one thyroid glands: study of thyroid glands obtained at necropsy in Colorado. AMA Arch Pathol 1955; 59:291-311.

4) Mortensen JD, Woolner LB, Bennett WA. Secondary malignant tumors of the thyroid gland:

Cancer 1956; 9:306-9

5) Shimaoka K, Sokal JE, Pickren JW. Metastatic neoplasms in the thyroid gland: Pathological and clinical findings. Cancer 1961; 15:557-65.

6) Silverberg SG, Vidone RA. Metastatic tumors in the thyroid. Pacific Med Surg 1966; 74:175-80.

7) Berge T, Lundberg S. Cancer in Malmo 1958-1969: An autopsy study. Acta Pathol Microbiol Scand Suppl 1977; 260:1-235.

8) Lam KY, Lo CY. Metastatic tumors of the thyroid gland: a study of 79 cases in Chinese patients. Arch Pathol Lab Med 1998; 122: 37-41. 
9) Wychulis AR, Beahrs OH, Woolner LB. Metastasis of carcinoma to the thyroid gland. Ann

Surg 1964; 160:169-77.

10) Czech JM, Lichtor TR, Carney JA, et al. Neoplasms metastatic to the thyroid gland. Surg Gynecol Obstet 1982; 155:503-5.

11) Ivy HK. Cancer metastatic to the thyroid: a diagnostic problem. Mayo Clin Proc 1984; 59:856-59.

12) Smith SA, Gharib H, Goellner JR. Fine-needle aspiration: Usefulness for diagnosis and management of metastatic carcinoma to the thyroid gland. Arch Intern Med 1987; 147:311-12.

13) Sasaki M. An evaluation of FDG-PET in the detection and differentiation of thyroid tumours. Nuclear Med Comm 1997; 18 : 957-63.

14) Rosen IB, Walfish PG, Bain J, et al. Secondary malignancy of the thyroid gland and its management. Ann Surg Oncol 1995; 2:252-56.

15) Nakhjavani MK, Gharib H, Goellner JR, et al. Metastasis to the thyroid gland: A report of 43 cases. Cancer 1997; 79:574-78.

16) Chen H, Nicol T.L, Udelsman R. Clinically significant, isolated metastatic disease to the thyroid gland. World J of Surg 1999; 23:177-81. 
17) Kim TY, Kim WB, Gong G, et al. Metastasis to the thyroid diagnosed by fine-needle aspiration biopsy. Clin Endocrinol 2005;

$62: 236-41$

18) Papi G, Fadda G, Corsello SM, et al. Metastases to the thyroid gland. prevalence,clinicopathological aspects and prognosis: a 10-year experience. Clin Endocrinol $2007 ; 66: 565-71$.

19) Burt A, Goudie RB. Diagnosis of primary thyroid carcinoma by immunohistological demonstration of thyroglobulin. Histopathology 1979; 3:279-86.

20) Hurlimann J, Gardiol D, Scazziga B. Immunohistology of anaplastic thyroid carcinoma: A study of 43 cases. Histopathology 1987; 11:567-80. 


\section{Figure legends}

Figure 1. Case 1. F-18-fluorodexoxyglucose positron emission tomography scan.

Hypermetabolic lesions are seen in the neck (black arrow), and in the right lung (white arrow).

Figure 2. Case1. Computed tomography scan showing tumor lesion in the right lobe of the

thyroid ( $A$, black arrow), as well as a tumor in the right upper lobe of the lung (B, black arrow).

Figure 3. Histological findings of the thyroid tumor show (A) carcinoma with papillary structures

(hematoxylin and eosin staining, $\times 40$ ). (B) Immunohistochemistry shows negative for thyroglobulin in tumor cells while positive for normal thyroid tissue $(\times 40)$. (C) Tumor cells are positive for cytokeratin $19(\times 40)$ (black arrow). 


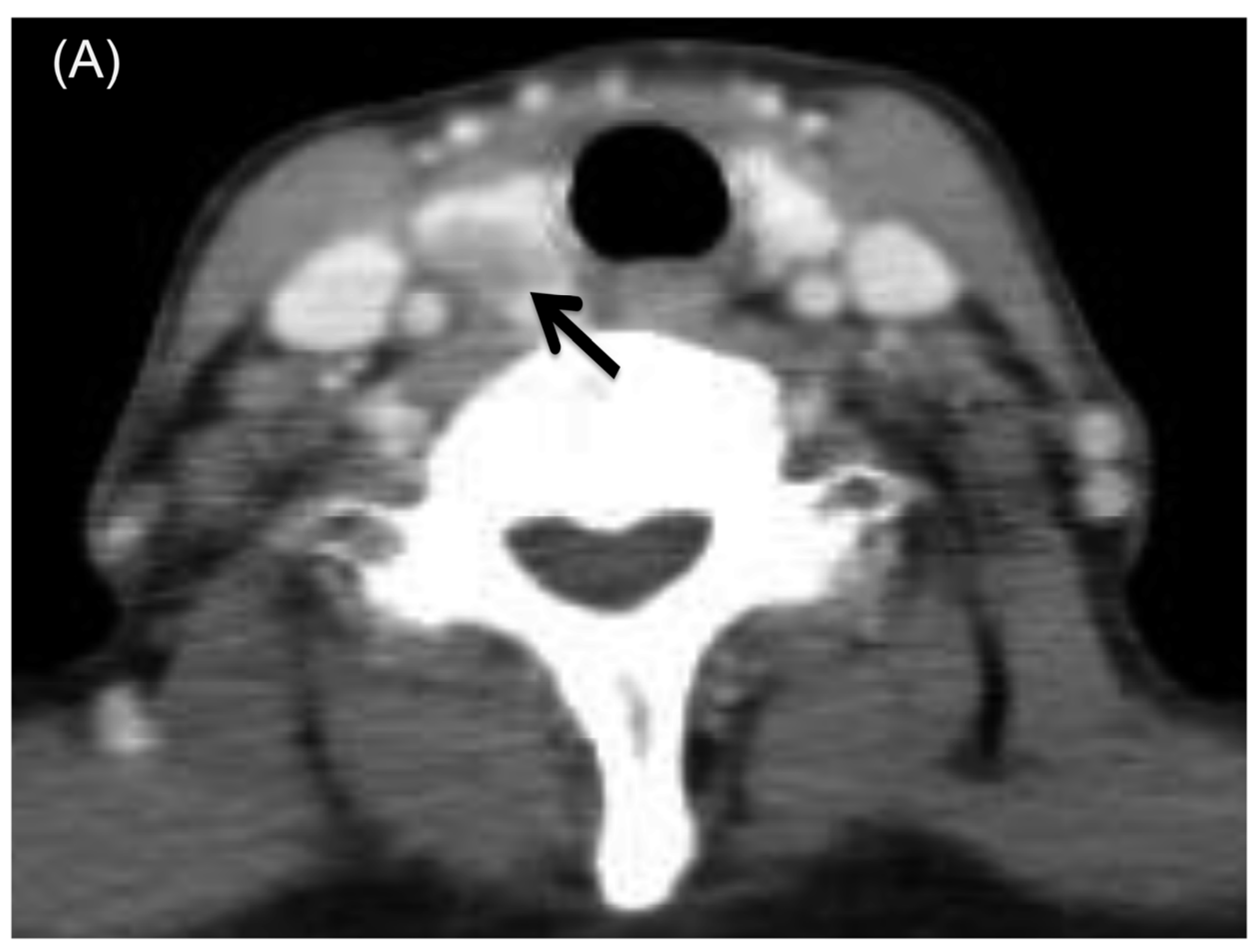




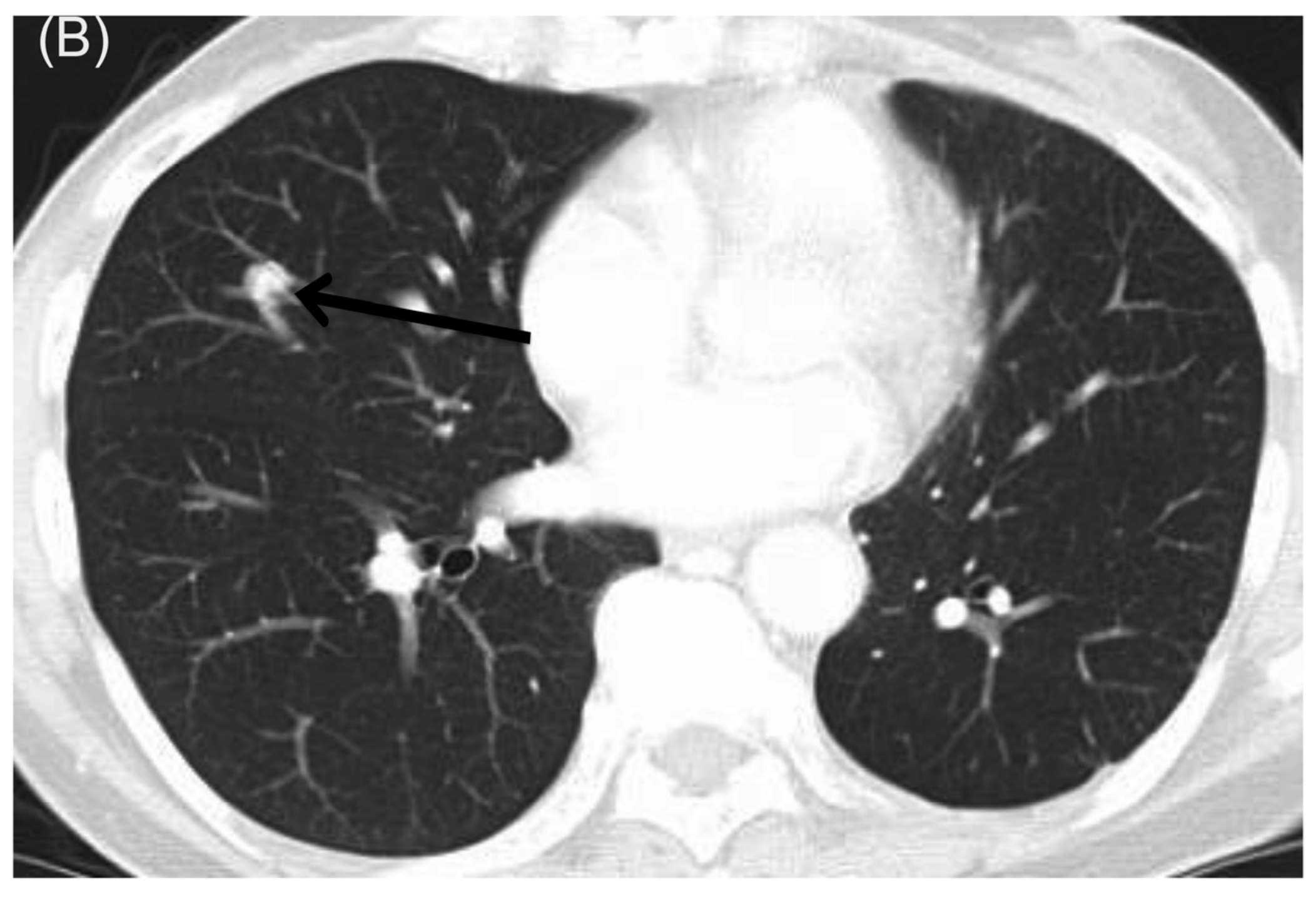




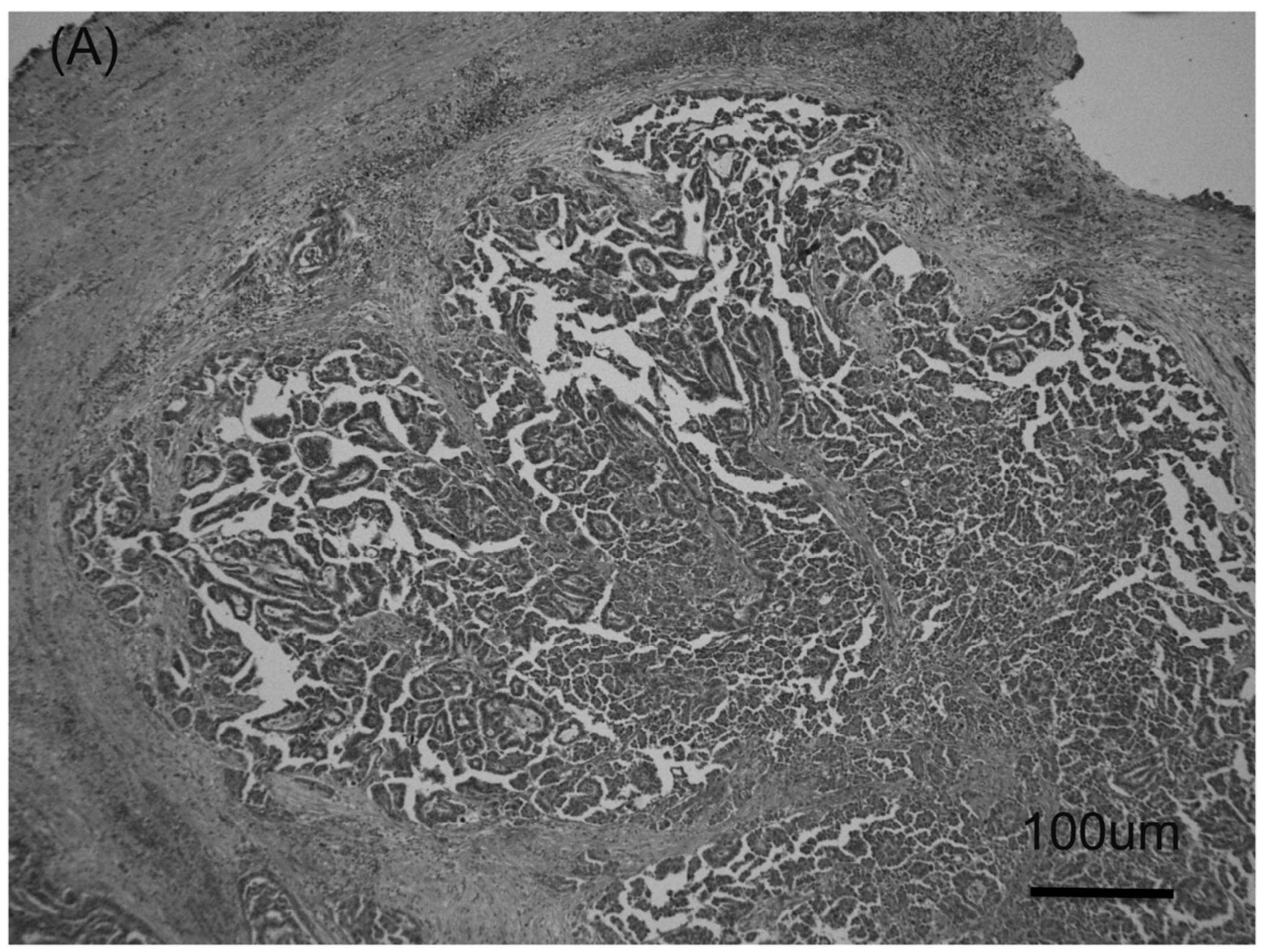




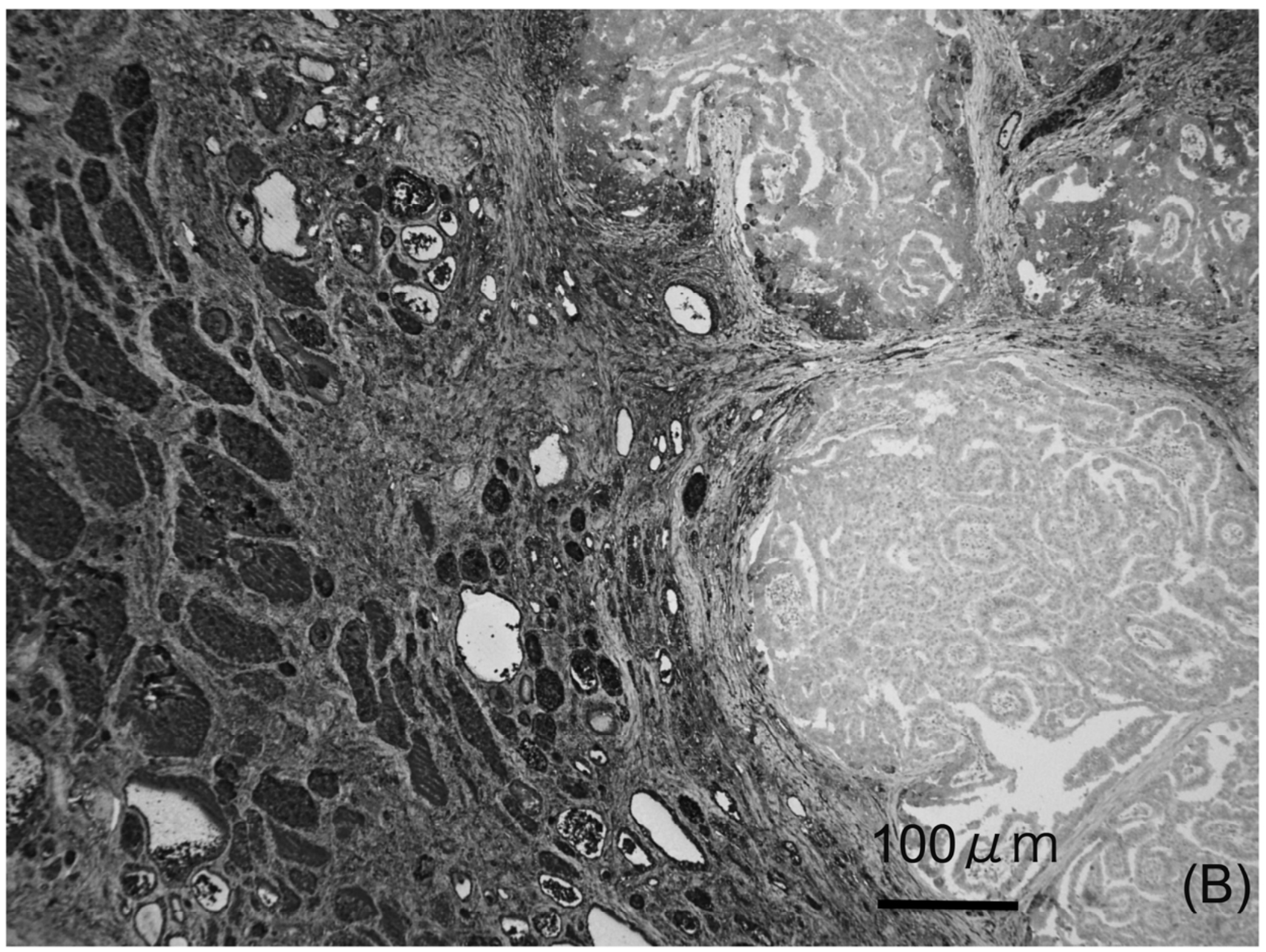




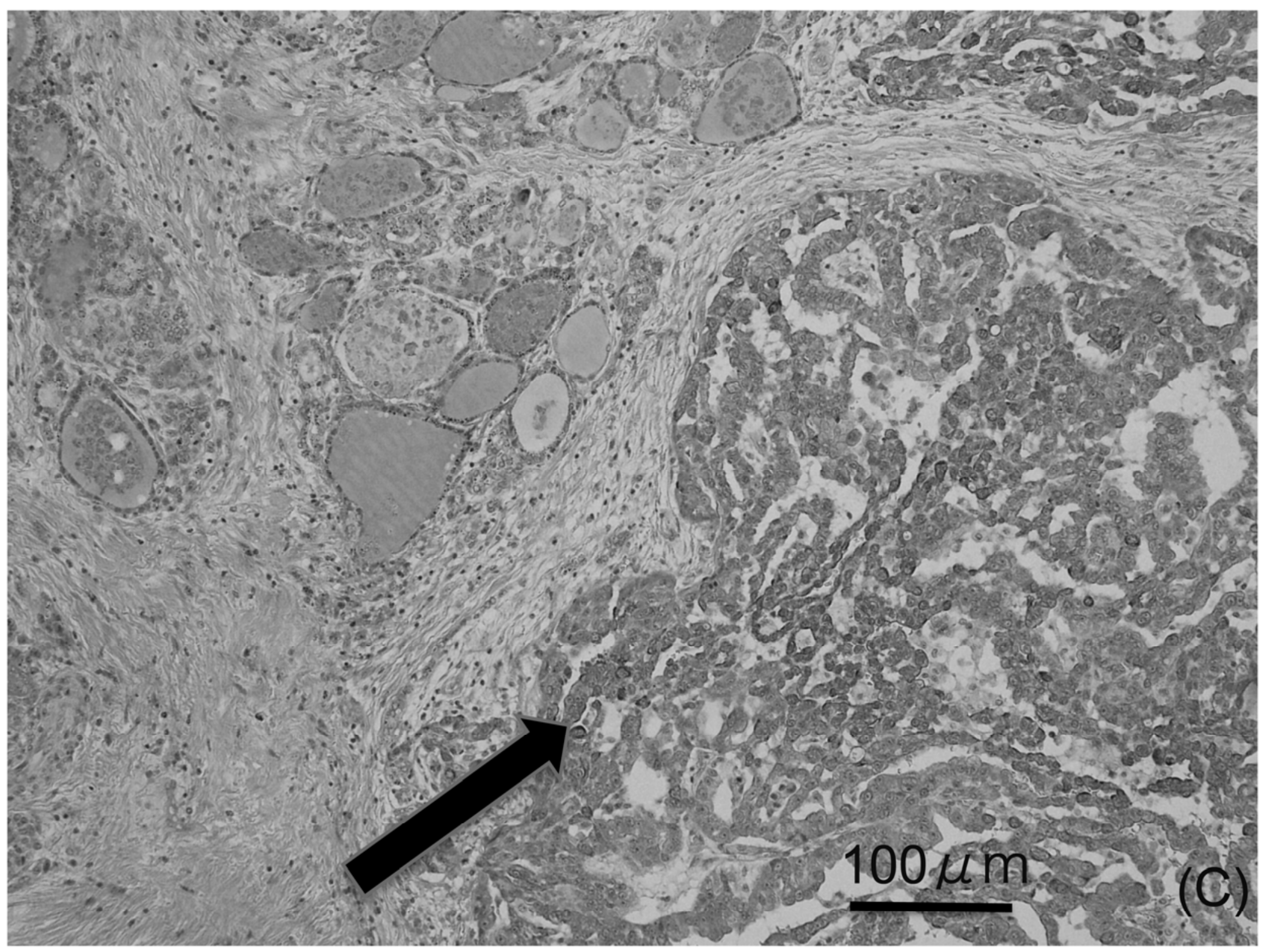


Table 1. Incidence of metastases to thyroid gland in autopsy series

\begin{tabular}{|c|c|c|c|c|c|}
\hline Authors & $\begin{array}{l}\text { Study } \\
\text { years }\end{array}$ & $\begin{array}{l}\text { No. of } \\
\text { cases }\end{array}$ & $\begin{array}{c}\text { Thyroid } \\
\text { metastasis } \\
(\%)\end{array}$ & $\begin{array}{l}\text { Common primary } \\
\text { sites of metastasis }\end{array}$ & Comments \\
\hline Rice $^{1)}$ & 1933 & 89 & 10.1 & Uncertain & Known primary cancer \\
\hline Abrams et al. ${ }^{2)}$ & $1943 \sim 1947$ & 1000 & 1.9 & Breast, lung & Unselected case \\
\hline $\mathrm{Hull}^{3)}$ & $1952 \sim 1953$ & 59 & 16.9 & Lymphoid tissue & Known primary cancer \\
\hline Mortensen et al. ${ }^{4)}$ & $1951 \sim 1953$ & 467 & 3.9 & Lymphoid tissue, lung, breast & Known primary cancer \\
\hline Shimaoka et al. ${ }^{5)}$ & $1955 \sim 1960$ & 1980 & 9.5 & Breast, Lymphoid tisse, lung & Known primary cancer \\
\hline Lam and Lo ${ }^{8)}$ & $1971 \sim 1995$ & 12955 & 0.5 & Lung, stomach, breast, & Unselected case \\
\hline
\end{tabular}


Table 2. Characteristic of patients with metastasis to the thyroid gland in current series

\begin{tabular}{|c|c|c|c|c|c|c|c|c|c|c|}
\hline Case & Age & Gender & $\begin{array}{l}\text { Primary } \\
\text { tumor site }\end{array}$ & $\begin{array}{l}\text { Clinical } \\
\text { presentation } \\
\text { of thyroid } \\
\text { metastasis }\end{array}$ & $\begin{array}{l}\text { Time to } \\
\text { detection } \\
\text { of thyroid } \\
\text { metastasis } \\
\text { (years) }\end{array}$ & $\begin{array}{l}\text { Metastases } \\
\text { elsewhere }\end{array}$ & $\begin{array}{l}\text { cytological } \\
\text { findings }\end{array}$ & Immunohistochemistry & Treatment & $\begin{array}{l}\text { Prognosis } \\
\text { (months) }\end{array}$ \\
\hline 1 & 69 & Female & Lung & FDG-PET & 1 & Lung & $\begin{array}{l}\text { Adenocaricinoma } \\
\text { with papillary } \\
\text { structure }\end{array}$ & $\begin{array}{l}\text { thyroglobulin }(-) \\
\qquad \text { CK19 (+) }\end{array}$ & $\begin{array}{c}\text { Total } \\
\text { thyroidectomy }\end{array}$ & 12 Alive \\
\hline 3 & 48 & Female & Breast & $\begin{array}{l}\text { dysphagia } \\
\text { dyspnea }\end{array}$ & 1 & $\begin{array}{l}\text { Lymph node } \\
\text { Lt precordial } \\
\text { skin }\end{array}$ & Adenocarcinoma & $\begin{array}{c}\text { Estrogen-Receptor (-) } \\
\text { Progesterone-Receptor (-) } \\
\text { HER-2 }(3+)\end{array}$ & $\begin{array}{c}\text { Total } \\
\text { thyroidectomy }\end{array}$ & 6 \\
\hline
\end{tabular}


Table 3. Incidence of metastases to thyroid gland in clinical series.

\begin{tabular}{|c|c|c|c|c|}
\hline Authors & $\begin{array}{l}\text { Study } \\
\text { years }\end{array}$ & $\begin{array}{l}\text { No. of } \\
\text { cases }\end{array}$ & $\begin{array}{c}\text { Common primary } \\
\text { sites of } \\
\text { metastasis }\end{array}$ & Comments \\
\hline Wychulis et al. ${ }^{9}$ & $1907 \sim 1962$ & 14 & Kidney, breast & Surgical cases \\
\hline Czech et al. ${ }^{10)}$ & $1960 \sim 1980$ & 12 & Kidney, breast, lung & Surgical cases \\
\hline $\mid \operatorname{lvy}^{11)}$ & 1946 1982 & 30 & Kidney, breast, lung & Surgical cases \\
\hline Smith et al. ${ }^{12)}$ & 1980 1985 & 15 & Breast, lung, kidney & Diagnosed by FNAB \\
\hline Rosen et al. ${ }^{14)}$ & $1978 \sim 1993$ & 11 & Various origin & Surgical cases \\
\hline Nakhjavani et al. ${ }^{15)}$ & 1985 1994 & 39 & Breast, kidney, lung & $\begin{array}{c}\text { Majority diagnosed } \\
\text { by FNAB }\end{array}$ \\
\hline Chen et al. ${ }^{16)}$ & 1986 1994 & 10 & Kidney & Surgical cases \\
\hline Kim et al. ${ }^{17)}$ & $1997 \sim 2003$ & 22 & Breast, lung, colon, kidney & Diagnosed by FNAB \\
\hline Papi et al. ${ }^{18)}$ & 1993 2003 & 36 & Lung, kidney, oesophagus & $\begin{array}{c}\text { Surgical cases } \\
\text { and } \\
\text { diagnosed by FNAB }\end{array}$ \\
\hline
\end{tabular}

